\title{
PENINGKATAN KETERAMPILAN KELOMPOK PEMBUDIDAYA IKAN DESA KARANGNANGKA KABUPATEN BANYUMAS MELALUI PEMANFAATAN LIMBAH SAYURAN SEBAGAI SUPLEMEN PELET IKAN
}

\author{
Dwi Nugroho Wibowo ${ }^{1}$, Dian Bhagawati ${ }^{1 *}$, Ani Widyastuti ${ }^{1}$, Erie Kolya Nasution ${ }^{1}$, \\ Kusbiyanto', Indarmawan', Siti Rukayah ${ }^{1}$ \\ ${ }^{1}$ Universitas Jenderal Soedirman, Puwokerto, Indonesia \\ *dian.bhagawati@unsoed.ac.id
}

\begin{abstract}
Abstrak: Sampah pasar tradisional umumnya berupa sisa sayuran, buah-buahan, daundaun, nasi dan lainnya yang dapat menimbulkan bau tidak sedap dan mengurangi estetika lingkungan. Upaya yang dapat dilakukan dalam meminimalisir dampak negatif dari limbah pasar tersebut diantaranya adalah dengan mengolahnya menjadi bahan pakan ikan. Bahan pakan ikan dengan memanfaatkan limbah sayuran tersebut akan dapat menekan biaya pakan khususnya bagi anggota pembudidaya ikan di Desa Karangnangka, Kecamatan Kedungbanteng Kabupaten Banyumas. Program pengabdian kepada masyarakat dengan tema alih teknologi ini bertujuan untuk mengedukasi dan melatih anggota pembudidaya ikan dalam pembuatan tepung nabati dari limbah pasar untuk suplemen pakan buatan yang diaplikasikan pada pakan ikan nila. Metode yang digunakan adalah Participatory Action Research (PAR) yang dikemas dalam bentuk pelatihan dengan tahapan antara lain adalah tahap persiapan, tahap implementasi dan tahap upaya keberlanjutan program. Hasil pengabdian menunjukkan melalui program pelatihan dalam pengabdian kepada masyarakat ini anggota pembudidaya ikan mampu membuat pelet untuk pakan ikan nila yang dilengkapi dengan tepung limbah nabati atau bahan lokal lainnya. Angka kelulushidupan benih ikan nila yang diberi pakan pelet dari bahan limbah sayuran tergolong baik. Dapat disimpulkan bahwa pelaksanaan pelatihan ini mampu menambah pengetahuan dan keterampilan anggota pembudidaya ikan dalam pembuatan pelet pakan ikan dengan memanfaatkan limbah sayuran. Pelet pakan ikan yang dihasilkan dapat disimpan dalam waktu lama dan mampu menekan biaya pakan pada proses pembudidayaan ikan.
\end{abstract}

Kata Kunci: limbah sayuran, pakan buatan, ikan nila

\begin{abstract}
Traditional market waste is generally in the form of remnants of vegetables, fruits, leaves, rice, and others, which usually cause unpleasant odors and reduce aesthetics. Efforts that can be made to minimize the negative impact of market waste include optimizing its potential for fish feed ingredients, to reduce feed costs, especially for members of fish cultivators in Karangnangka Village, Kedungbanteng District, Banyumas Regency. This community service program with the theme of technology transfer aims to educate and train members of fish farmers in making vegetable flour from market waste for artificial feed supplements applied to tilapia feed. The method used in this program was Participatory Action Research (PAR) through several stages, including the preparation stage, implementation stage, and the stage of program sustainability efforts. The results of the program show that through this program, fish cultivators are able to make pellets for tilapia feed equipped with vegetable waste flour or other local materials. The survival rate of tilapia seeds fed with pellets from vegetable waste is relatively good. It can be concluded that the implementation of this program is able to increase the knowledge and skills of members of fish cultivators in making fish feed pellets by utilizing vegetable waste. The result of fish feed pellets can be stored for a long time and can reduce feed costs in the fish farming process.
\end{abstract}

Keywords: vegetable waste, artificial feed, tilapia 


\section{Pendahuluan}

Pembudidaya ikan di Desa Karangnangka Kecamatan Kedungbanteng, Kabupaten Banyumas sebagian besar menekuni kegiatan sebagai penghasil telur ikan Gurami. Berdasarkah hasil jejak pendapat, diperoleh informasi bahwa pada musim-musim tertentu produksi telur mengalami penurunan kualitas maupun kuantitasnya, sehingga penghasilan petani ikan menjadi sangat menurun. Untuk mengatasi kondisi tersebut, beberapa pembudidaya ikan telah melakukan diversifikasi komoditas budidaya dengan memelihara ikan nila. Awalnya usaha budidaya ikan nila yang dilakukan dapat berjalan lancar, namun lama kelamaan muncul kendala yang berupa keterbatasan modal untuk penyediaan pakan dan benih. Terkait dengan ketersediaan pakan, karena belum mampu memproduksi pakan buatan, maka pakan yang diberikan tidak kontinyu, dampaknya produktivitas budidayanya menjadi rendah.

Berdasarkan penjelasan anggota kelompok pembudidaya ikan (Pokdakan) di RT 01/RW03 dan di RT 02/RW06, aktivitas memelihara ikan nila tersebut sudah dilakukan sejak tahun 2014, namun cara pemeliharaannya masih konvensional. Bahkan pemberian pakan yang dilakukan tidak memperhatikan nilai gizinya, sehingga ikan yang dipelihara badannya kurus dan hanya kepalanya yang bertambah besar. Adanya permasalahan tersebut mendorong pokdakan untuk menambah pengetahuan dan keterampilannya dalam mengelola pakan untuk ikan yang dipeliharanya. Anggota pokdakan berharap agar dapat dilakukan pelatihan pembuatan pakan ikan dengan memanfaatkan limbah yang terdapat di lingkungannya. Hasil musyawarah anggota pokdakan memutuskan agar dapat dilakukan pelatihan dan praktek pembuatan pakan ikan dengan memanfaatkan limbah sayuran (berasal dari limbah dapur maupun pasar). Untuk mendukung terealisasinya kegiatan tersebut mereka sanggup menyediakan lahan untuk membuat kolam sebagai sarana demonstrasi plot (demplot) serta tenaga untuk merawatnya. Harapannya, dengan tambahan bekal ilmu dan keterampilan tersebut maka ikan yang dipelihara dapat tumbuh dengan baik dan sehat, serta dapat memanen hasil budidayanya secara optimal.

Dipilihnya limbah sayuran sebagai salah satu sumber pakan karena kandungan gizinya dapat mendukung pertumbuhan ikan. Walaupun data tentang volume limbah sayuran di Desa Karangnangka belum terdokumentasi secara pasti, namun jumlahnya relatif banyak, yaitu berasal dari rumah tangga, kebun dan pasar tradisional. Limbah sayuran juga mampu meningkatkan higiene lingkungan, karena limbah sayuran yang tidak dikelola dengan baik dan dibiarkan membusuk akan menimbulkan pemandangan dan bau yang tidak sedap. Ihsan et al. (2020) berpendapat bahwa salah satu solusi pengembangan industri budidaya yang ramah lingkungan secara berkelanjutan dapat dilakukan dengan memproduksi pakan buatan berbahan limbah.

Rusmana et al. (2007) telah melakukan analisis kandungan gizi tepung limbah sayuran yang diolah dan tidak diolah, sebelum dikeringkan dan digiling. Hasilnya menunjukkan bahwa tepung limbah sayuran yang sebelumnya tidak diolah memiliki kandungan gizi yang lebih baik. Hasil selengkapnya tertera pada Tabel 1. 
Wibowo, D.N., Bhagawati, D., Widyastuti, A., Kolya, E., Kusbiyanto, Indarmawan, Rukayah, S. Peningkatan...

Tabel 1. Kandungan Gizi Tepung Limbah Sayuran dengan Cara Pengolahan Berbeda (Basis 90\% Bahan Kering)

\begin{tabular}{llll}
\hline Cara pengolahan & Protein & Serat & Energi \\
& Kasar $(\%)$ & Kasar $(\%)$ & Bruto (Kkal/kg \\
\hline Segar/tanpa pengolahan & 21,16 & 14,28 & 3571 \\
Pengolahan dengan pengukusan & 20,52 & 14,14 & 3464 \\
Pengolahan dengan perebusan & 20,10 & 13,85 & 3393 \\
Pengolahan dengan penjemuran & 20,95 & 14,21 & 3500 \\
\hline
\end{tabular}

(Sumber: Rusmana et al., 2007)

Atas dasar persoalan yang dihadapi, maka dapat dirumuskan permasalahan pada anggota pokdakan Desa Karangnangka Kecamatan Kedungbanteng Kabupaten Banyumas, yaitu: 1) khalayak sasaran perlu dididik dan diberi pengetahuan tentang pakan tambahan untuk ikan nila, serta membuat tepung limbah sayuran; 2) khalayak sasaran perlu dimotivasi, didorong dan dibiasakan memberikan pakan tambahan untuk ikan yang dipeliharanya dengan pakan buatan yang diproduksi sendiri, dengan memanfaatkan limbah yang terdapat di lingkungannya. Tujuan kegiatan pengabdian kepada masyarakat dengan tema alih teknologi ini adalah 1) mendidik dan melatih khalayak sasaran membuat tepung limbah sayuran sebagai suplemen untuk pakan ikan; dan 2) mengaplikasikan produksi pakan untuk memelihara benih ikan nila. Hasil kegiatan diharapkan mampu mengatasi permasalahan yang dihadapi khalayak sasaran dalam pengadaan pakan ikan secara mandiri serta mampu mengurangi biaya pakan yang harus dikeluarkan.

Menurut Bhagawati et al. (2019), seringkali upaya pemenuhan kebutuhan pakan ikan menimbulkan dilema. Di satu sisi, dituntut untuk memberikan pakan berkualitas agar ikan dapat tumbuh dengan baik, di sisi lain harga pakan tambahan menjadi pembatas bagi pembudidaya, karena modalnya terbatas. Oleh karena itu, memproduksi pelet dengan memanfaatkan bahan limbah merupakan salah satu upaya menjaga stabilitas usaha budidaya ikan.

\section{Metode}

Program alih teknologi ini dilaksanakan mulai bulan Mei 2017 sampai dengan September 2017. Tim pengabdi terdiri atas 6 orang dosen dengan latar belakang keilmuan yang mendukung, yaitu biologi gulma, ekologi hewan, ekologi tumbuhan, dan akuakultur. Kegiatan bertempat di lokasi khalayak sasaran yang merupakan anggota kelompok pembudidaya ikan (Pokdakan) di RT 01/RW03 dan di RT 02/RW06 Desa Karangnangka Kabupaten Banyumas.

Tahap kegiatan yang dilaksanakan, yaitu: 1) persiapan; 2) implementasi; 3) dan keberlanjutan, dengan menerapkan metode partisipatif (Participatory Action Research /PAR) yang dikemas dalam bentuk pelatihan. Langkah-langkah kegiatan ditampilkan pada Gambar 1. Menurut Afandi (2020), implementasi Participatory Action Research (PAR) dalam kegiatan pengabdian masyarakat adalah proses pendekatan yang bertujuan untuk pembelajaran guna mengatasi masalah, memenuhi kebutuhan praktis masyarakat, produksi ilmu pengetahuan dan, dan proses perubahan sosial keagamaan. 


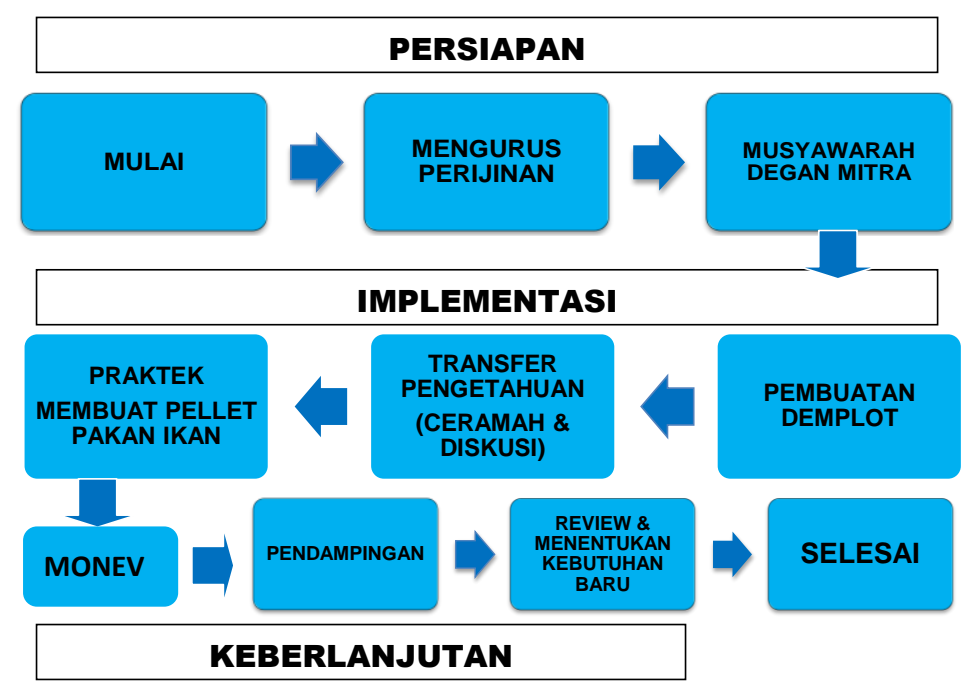

Gambar 1. Bagan alur pelaksanaan kegiatan

Materi pelatihan yang diberikan yaitu tentang bahan-bahan untuk membuat pelet, menyusun formula pakan dan menghitung kebutuhan bahan dengan metode bujur sangkar. Alat yang digunakan untuk mendukung pelaksanaan kegiatan yaitu alat tulis, alas plastik, pisau, talenan kayu, baskom plastik, kantong plastik, centong plastik, gilingan daging, ayakan plastik, timbangan, dandang dan kompor. Pelet dibuat dari tepung ikan, dedak halus, bungkil kelapa dan tepung sayuran. Mengingat tepung sayuran tidak dijual di pasaran maka khalayak sasaran terlebih dahulu dilatih untuk membuat tepung sayuran. Caranya yaitu dengan memilih limbah sayuran yang memiliki kandungan protein relatif tinggi, dicuci bersih, dijemur (Gambar 2) kemudian digiling hinga berbentuk tepung. Menurut Badan Litbang Pertanian (2013) kandungan protein limbah sayuran yang dapat dimanfaatkan sebagai pakan ternak nilainya bervariasi, misalnya pada limbah Sawi terdapat 27,59g/100g, Kol 20,30g/100g, kulit kecambah tauge $14,42 \mathrm{~g} / 100 \mathrm{~g}$, daun kembang kol $31,77 \mathrm{~g} / 100 \mathrm{~g}$, dan pada kulit jagung $1,94 \mathrm{~g} / 100 \mathrm{~g}$.

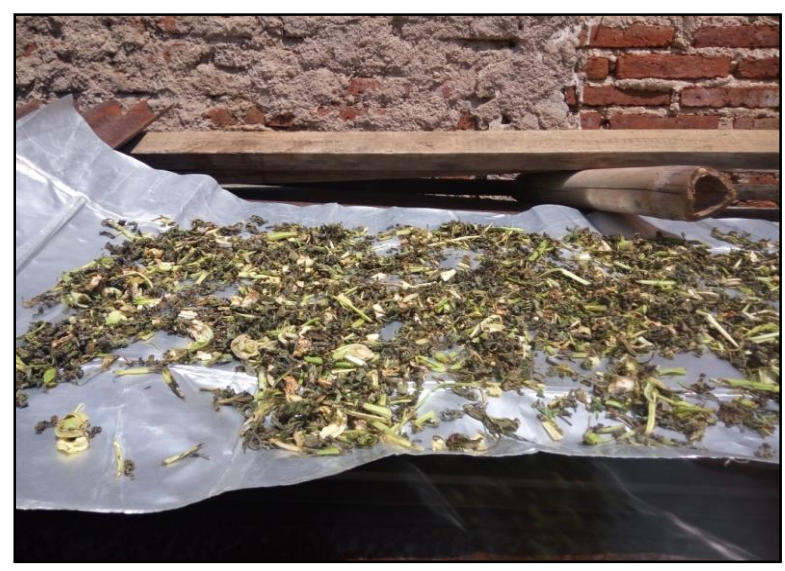

Gambar 2. Pengeringan Sayuran Limbah

Terdapat berbagai cara atau metode untuk menyusun formulasi pakan, yaitu: 1) metode Pearsons Square (Metode segi empat Pearsons), 2) metode Aljabar, 3) metode Linier (Program Linier), 4) Metode coba-coba (Trial and Error), dan 5) metode Worksheet 
Wibowo, D.N., Bhagawati, D., Widyastuti, A., Kolya, E., Kusbiyanto, Indarmawan, Rukayah, S. Peningkatan...

(Millamena et al, 2002). Namun yang umum dan mudah dilakukan adalah dengan metode empat persegi pearson's, metode persamaan aljabar, dan metode lembaran kerja (worksheet). Didalam menyusun formulasi pakan pada pelatihan ini, diterapkan metode Pearsons Square (Metode segi empat Pearsons), yang didasari oleh kadar protein bahanbahan pakan ikan (Millamena et al., 2002; Ali, 2015).

Kandungan protein pada bahan pakan ikan dapat dibedakan menjadi dua bagian, yaitu protein basal, yang merupakan bahan baku pakan ikan, dari unsur nabati, hewani dan limbah dengan kandungan protein kurang dari $20 \%$ dan protein suplement, berupa bahan baku pakan ikan, dari nabati, hewani dan limbah yang kandungan protein lebih dari $20 \%$.

Langkah-langkah perhitungan formulasi pakan ikan dengan metode pearsons, untuk membuat pakan dengan kandungan protein 30\% yaitu sebagai berikut.

1) Membuat rencana atau perkiraan yang akan digunakan untuk masing-masing bahan baku yang digunakan.

2) Mencari referensi tentang kandungan protein dari bahan baku yang tersedia dan akan digunakan. Contohnya, hasil penelusuran pustaka kandungan gizi masing-masing bahan, diperoleh data seperti yang tertera pada Tabel 2., maka nilai tersebut digunakan sebagai dasar untuk menyusun formula pakan ikan nila yang akan dibuat.

Tabel 2. Kandungan Gizi Bahan Pakan Ikan

\begin{tabular}{ll}
\hline Bahan & Protein (\%) \\
\hline Tepung limbah sayuran & 21,16 \\
Tepung ikan & 60 \\
Bungkil kelapa & 17,09 \\
Dedak & 11,35 \\
\hline Sumber: Rusmana et $a l, 2007)$ &
\end{tabular}

(Sumber: Rusmana et al., 2007)

Kelompok sumber protein utama adalah tepung ikan dan kelompok sumber protein adalah dedak, bungkil kelapa dan limbah pasar. Apabila akan menggunakan lebih dari 2 bahan baku, maka dikelompokkan dahulu bahan baku basal (kadar protein $<20 \%$ ) dan protein suplemen (>20\%), kemudian masing-masing kelompok dirata-ratakan dahulu, setelah itu dimasukkan ke metoda Pearsons Square (Segi Empat Pearsons)

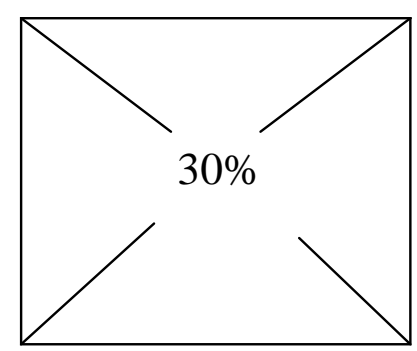

Perhitungan bahan:

Kadar protein bahan baku basal (dedak + bungkil kelapa $+\operatorname{limbah}$ pasar) $/ 3=$ $(11,35+17,09+21,16) / 3=49,6 / 3=16,53 \%$

Kadar protein suplemen tepung ikan $=60 \%$ 


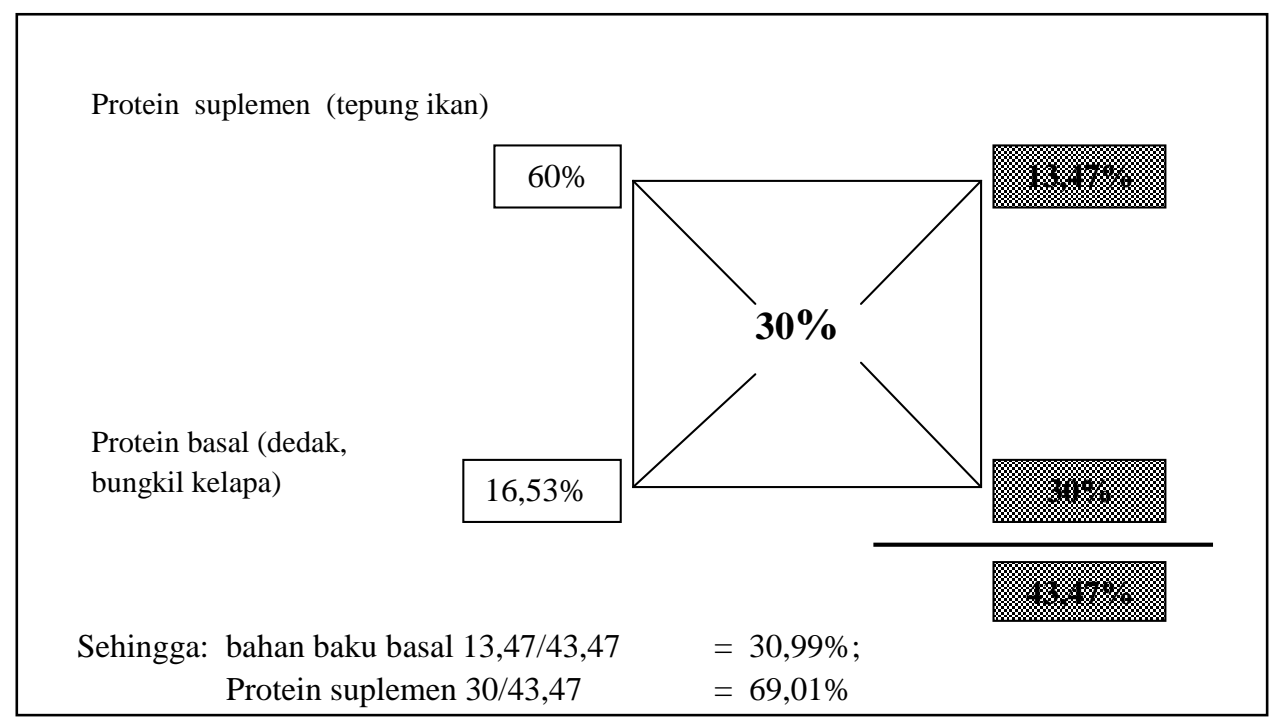

Gambar 3. Cara Menghitung dengan Metode Pearsons Square (segi empat Pearsons) (Sumber: Ali, 2015. Dimodifikasi)

Nilai protein pakan yang dibuat mengacu pada SNI 7550:2009 (Badan Standarisasi Nasional, 2009), dan pada pelatihan ini dicoba membuat formulasi pakan dengan kandungan protein $>30 \%$. Dasar penentuan nilai protein bahan baku merujuk pada Suyanto (2005), yang berpendapat bahwa pelet untuk pakan ikan nila dengan kadar protein 20-25\%, telah mampu mendukung pertumbuhannya.

Berdasarkan hasil perhitungan tersebut, bahan yang dibutuhkan untuk membuat $100 \mathrm{~kg}$ pakan ikan adalah dengan mencampurkan beberapa bahan sebagai berikut: dedak halus sebanyak 10,33.8 kg; bungkil kelapa 10,33 kg; tepung sayuran 10,33 kg dan protein suplemen sebanyak 69,01 kg. Namun karena dalam praktek ini hanya membuat $10 \mathrm{~kg}$ pelet, maka masing-masing bahan yang digunakan merupakan seper-sepuluh bagian dari semestinya.

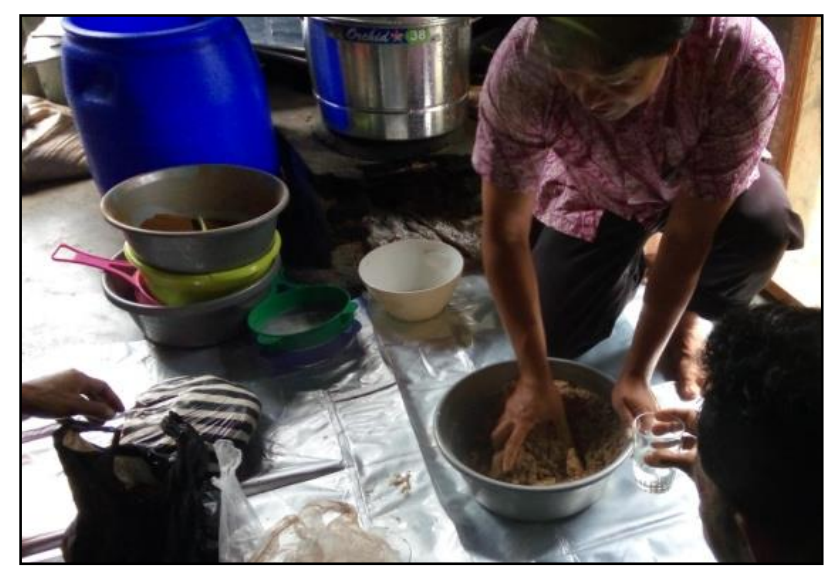

Gambar 4. Pengabdi Sedang Mendemonstrasikan Cara Mencampur Bahan

Bahan-bahan untuk membuat pelet, diayak terlebih dahulu kemudian ditimbang sesuai kebutuhan. Bahan pelet yang sudah disediakan sesuai dengan komposisinya dicampur sedikit demi sedikit (Gambar 4), diawali dari bahan yang bobotnya sedikit serta ditambah dengan tepung kanji (sebagai perekat). Apabila semua bahan sudah dicampur, kemudian diberi air 
Wibowo, D.N., Bhagawati, D., Widyastuti, A., Kolya, E., Kusbiyanto, Indarmawan, Rukayah, S. Peningkatan...

hangat secukupnya hingga adonan kalis, kemudian dikukus. Adonan yang sudah jadi, selanjutnya dicetak dengan gilingan daging. Hasil cetakan dijemur hingga kering, kemudian pelet yang sudah jadi disimpan di tempat yang kering. Pakan yang dibuat selanjutnya diaplikasikan untuk pakan benih ikan nila yang dipelihara dalam kolam terpal.

\section{Hasil dan Pembahasan}

Realisasi kegiatan ini secara kronologis dapat dibedakan menjadi tiga tahap, yaitu persiapan, pelaksanaan dan evaluasi. Tahap persiapan merupakan masa koordinasi antara tim pengabdi dengan khalayak sasaran, untuk menentukan waktu pelaksanaan, lokasi penyuluhan dan lokasi pembuatan demplot. Secara aktif seluruh peserta terlibat dalam setiap kegiatan. Selama kegiatan berlangsung dilakukan diskusi dan pengamatan terhadap kemampuan peserta dalam mengenali, memilih dan memproses bahan limbah sebagai sumber pakan ikan. Evaluasi dilakukan berdasarkan capaian fisik, non-fisik serta dampak yang ditimbulkan oleh adanya pelatihan ini, kemudian dianalisis secara deskriptif.

Tahap pelaksanaan meliputi penyuluhan, praktek membuat pelet dan membuat demplot pemeliharaan benih ikan nila. Penyuluhan direalisasikan dalam bentuk ceramah dan diskusi (Gambar 5), yang dilaksanakan pada malam hari, sebanyak dua kali yang diikuti oleh 19 dan 17 peserta, yang terdiri atas anggota pokdakan dan wakil perangkat desa.

Khalayak sasaran diminta membuat gambar sebuah bujur sangkar dan menuliskan nilai kandungan protein yang dikehendaki di tengah garis diagonal (Gambar 3). Posisi kiri atas pada bujur sangkar dituliskan nilai kandungan protein dari bahan dari sumber protein utama, sedangkan pada sisi kiri bawah adalah yang memiliki nilai kandungan protein lebih rendah, yaitu dari kelompok sumber protein penunjang). Saat praktek membuat pelet (Gambar 6), diikuti oleh 10 peserta. Sedikitnya peserta yang mengikuti praktek karena kegiatan tersebut dilaksanakan siang hari, dan pada saat bersamaan sebagian besar khalayak sasaran serta masyarakat setempat sedang bekerja di sawah.

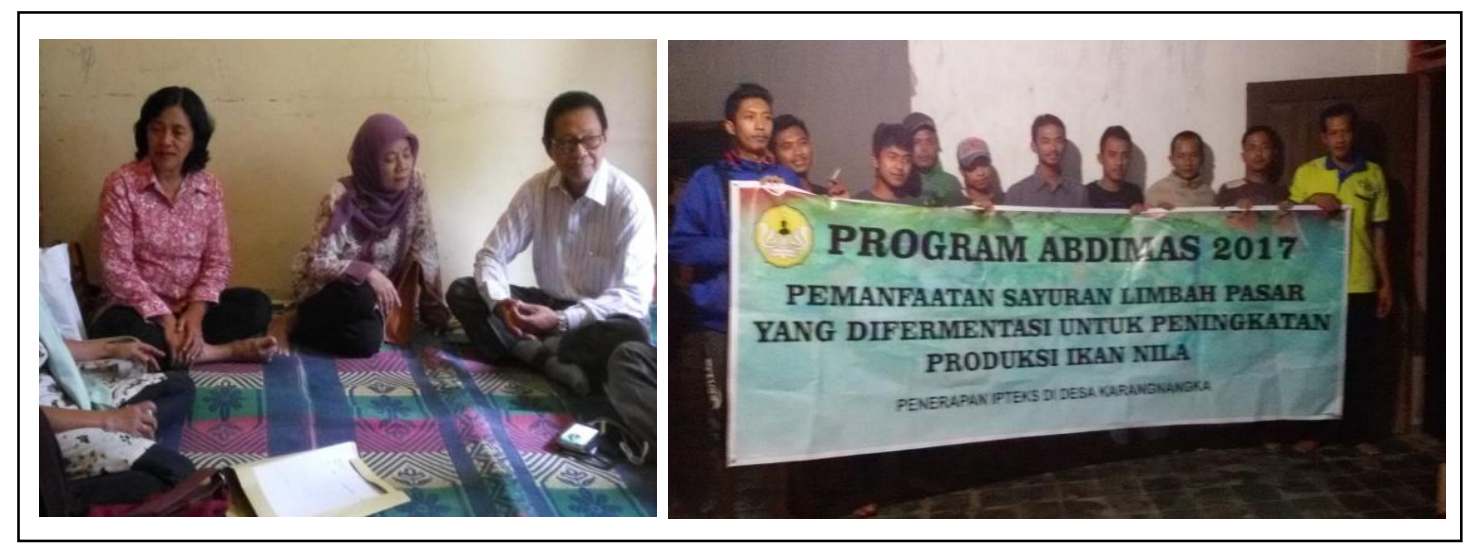

Gambar 5. Dokumentasi Pelaksanaan Penyuluhan

Evaluasi kegiatan dilakukan berdasarkan kondisi fisik dan non fisik, untuk mengukur perubahan pengetahuan, ketrampilan dan perilaku khalayak sasaran. Pemantauan dilakukan terhadap sikap dan aktivitas peserta selama mengikuti ceramah serta praktek membuat pelet. 


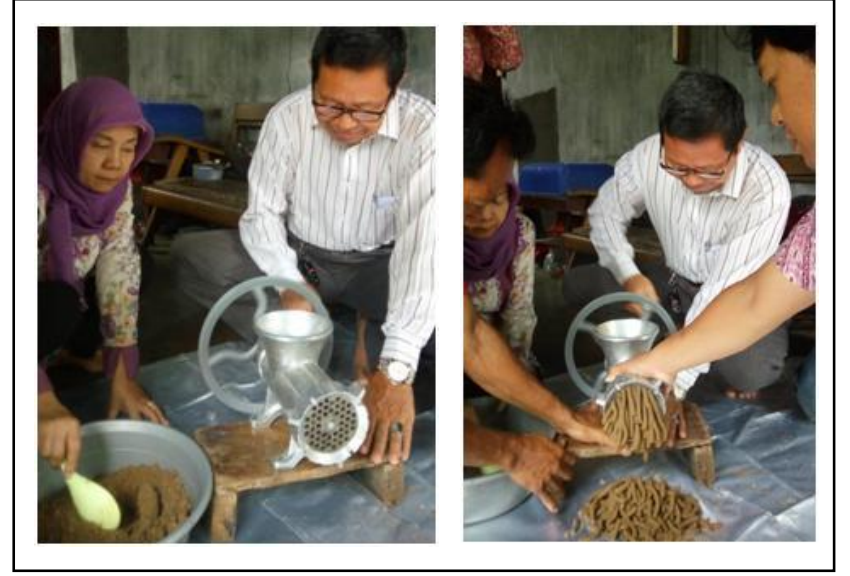

Gambar 6. Pengabdi Sedang Mendemonstrasikan Mencetak Pelet

Hasil evaluasi menunjukkan bahwa penyelenggaraan penyuluhan yang dilakukan dalam bentuk ceramah, diskusi, yang didukung dengan praktek membuat pelet, telah mampu meningkatkan pengetahuan peserta. Hasil pemantauan terhadap kemampuan peserta yang dilakukan dengan cara diskusi dan pengamatan selama pelaksanaan praktik serta mengelola demplot, menunjukkan bahwa $70 \%$ peserta telah mampu mengenali dan memilih bahan untuk membuat pelet. Dengan demikian dapat dikatakan bahwa materi penyuluhan dapat diterima dan dipahami oleh peserta.

Faktor pendorong yang menunjang keberhasilan pelaksanaan program pengabdian ini antara lain adalah adanya kerjasama yang baik antara tim pengabdi, khalayak sasaran serta dengan aparat setempat. Faktor penghambat dalam menerapkan teknologi ini adalah cuaca, yang sering mendung dan turun hujan, sehingga pengeringan pelet kurang optimal. Namun demikian, hambatan tersebut tidak terlalu berpengaruh terhadap penyediaan pakan untuk benih ikan nila, karena cara pemberiannya dengan menghancurkan pelet menjadi butiran kecil, sehingga lebih cepat kering. Selain itu, apabila kondisi pelet masih kurang kering, maka dibantu dengan di oven, menggunakan oven sederhana.

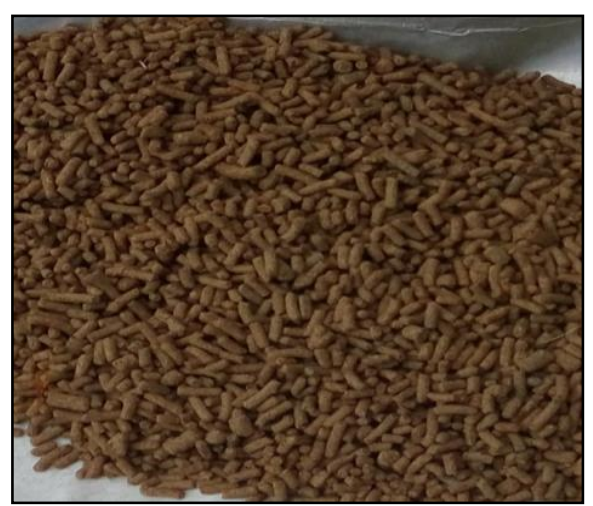

Gambar 7. Performa Pelet yang Dihasilkan

Kandungan protein pelet yang dibuat selama pelatihan mengacu pada SNI 7550:2009, tentang produksi ikan nila (Oreochromis niloticus) kelas pembesaran di air tenang; dan SNI 01-7242-2006 tentang Pakan Buatan Untuk Ikan Nila (Oreochromis spp) Pada Budidaya 
Wibowo, D.N., Bhagawati, D., Widyastuti, A., Kolya, E., Kusbiyanto, Indarmawan, Rukayah, S. Peningkatan...

Intensif. Disebutkan dalam SNI tersebut, bahwa agar ikan nila dapat tumbuh baik, maka dapat diberi pakan buatan berbentuk pelet yang mempunyai kadar protein $>25 \%$ dan pada pelatihan ini dicoba membuat formulasi pakan dengan kandungan protein $>30 \%$.

Meskipun tidak dilakukan pemeriksaan secara khusus terhadap kandungan gizi pelet yang dihasilkan, namun dari hasil uji kualitatif performanya dapat dikenali bahwa pelet yang dihasilkan tergolong berkualitas. Uji kualitatif kualitas pakan yang diakukan mengacu pada Yulianto (2018) dan Saade \& Aslamyah (2009). Hasil pengamatan yang diperoleh adalah warna pelet menyerupai pakan pabrikan (Gambar 7), tidak berbau amoniak, tidak mudah hancur, dan tidak cepat tenggelam. Menurut Saade \& Aslamyah (2009), kualitas pelet pakan ikan dapat dikenali dari kondisi fisik dengan melihat kekuatan apung, kecepatan tenggelam sampai dasar dan stabilitas/lama hancur di dalam air. Stabilitas pakan dalam air adalah tingkat ketahanan pakan di dalam air atau berapa lama waktu yang dibutuhkan hingga pakan lembek dan hancur.

Berdasarkan pendapat Yulianto (2018) dan Saade \& Aslamyah (2009), dapat dimaknai bahwa kualitas pakan, baik secara fisik, kimia dan biologi sangat menentukan performa pakan, respon ikan terhadap aroma, rasa dan tekstur pakan. Dampaknya pakan tersebut dapat dicerna oleh ikan, dan mampu menyediakan nutrient serta energi. Di samping itu pakan yang berkualitas akan melindungi ikan dari malnutrisi, infeksi, serangan penyakit serta mempercepat penyembuhan bagi ikan yang sakit.

Pelet yang dihasilkan juga mampu mendukung kelangsungan hidup dan pertumbuhan benih ikan nila yang dipelihara selama satu bulan dalam kolam terpal (Gambar 8). Hal ini dapat dilihat dari rendahnya tingkat kematian (5\%) serta terjadinya pertumbuhan yang dialami oleh benih ikan nila. Selama satu bulan, benih mengalami pertambahan panjang tubuh antara 10-12 mm (Gambar 9). Terjadinya pertumbuhan yang dialami benih ikan nila pada demplot yang dibuat pada pelatihan ini, menunjukkan bahwa kandungan gizi pakan yang diberikan cukup baik dan mampu mendukung pertumbuhan benih tersebut.

Pertambahan panjang tubuh yang dialami oleh benih ikan nila yang dipelihara selama pelatihan tersebut tergolong baik, dan relatif sama dengan hasil penelitian Tiani \& Narayana (2018). Benih ikan nila yang dipelihara oleh Tiani \& Narayana (2018) di kolam, selama 21 hari dan diberi pakan alami dan pakan tambahan perupa pelet mengalami pertumbuhan panjang mutlak mencapai $11 \mathrm{~mm}$.

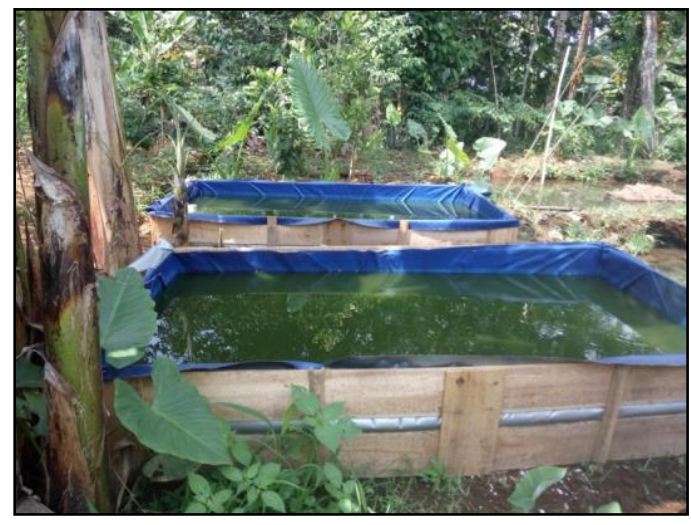

Gambar 8. Kolam Terpal Untuk Pendederan Benih Ikan Nila 


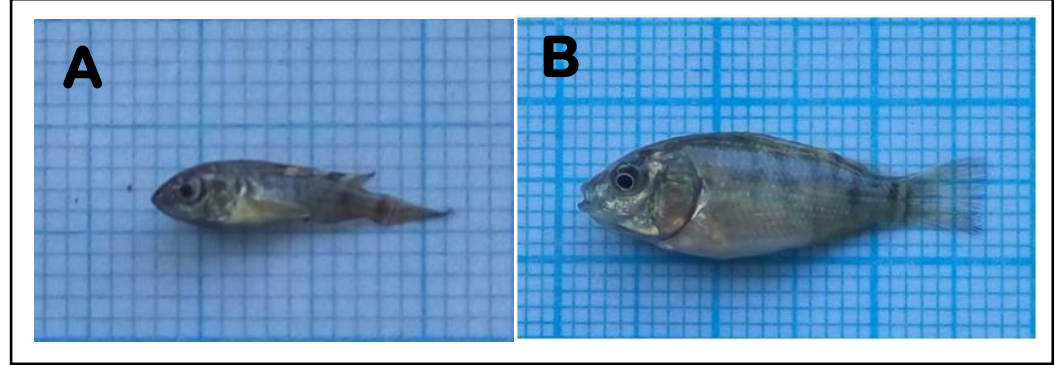

Gambar 9. Benih Ikan Nila Hasil yang dipelihara dalam kolam terpal. Keterangan: A. Ukuran Benih Awal Pemeliharaan B. Ukuran Benih Akhir Pemeliharaan setelah dipelihara selama 21 hari

Menurut Masyamsir (2001), sebagian besar ( $\pm 50 \%)$ dari kebutuhan kalori yang diperlukan oleh ikan berasal dari protein. Bahan ini berfungsi untuk membangun otot, sel-sel dan jaringan tubuh, terutama bagi ikan-ikan muda. Kebutuhan protein sendiri bervariasi tergantung pada jenis ikannya. Meskipun demikian, protein adalah unsur yang diperlukan untuk pertumbuhan dan kesehatan pada seluruh jenis ikan. Umumnya, ikan membutuhkan protein lebih banyak daripada hewan-hewan ternak di darat (unggas dan mamalia). Jenis dan umur ikan juga berpengaruh pada kebutuhan protein. Ikan karnivora membutuhkan protein yang lebih banyak daripada ikan herbivora, sedangkan ikan omnivora berada diantara keduanya. Pada umumnya ikan membutuhkan protein sekitar 20-60\%, dan optimum 30 36\% (Masyamsir, 2001).

Widyastuti et al. (2014) telah berhasil mengaplikasikan pelet fermentasi yang terbuat dari bahan baku berupa dedak, bungkil kelapa, ampas tahu dan tepung daun caisin. Bahan baku yang digunakan dengan perbandingan $1: 1: 1$, dan daun caisin dengan konsentrasi $0 \%$, $5 \%, 10 \%$ dan $15 \%$. Lebih jauh dijelaskan bahwa fermentasi bahan pakan yang berupa limbah pertanian dengan suplemen tepung daun caisin dapat meningkatkan kadar protein kasar antara $10-30 \%$. Pakan fermentasi dari limbah pertanian dengan suplemen tepung daun caisin dan pemberian probiotik mampu meningkatkan pertumbuhan ikan di perairan waduk. Penambahan tepung daun caisin dengan konsentrasi 5\% memberikan dampak terbaik terhadap pertambahan bobot dan biomassa ikan nila.

Pakan dengan kandungan nutrisi yang baik dapat mempercepat laju pertumbuhan ikan karena zat tersebut akan dipergunakan untuk menghasilkan energi dan mengganti sel-sel tubuh yang rusak. Sementara itu, nutrisi pakan buatan sangat tergantung dengan bahan penyusunnya, sehingga didalam merencanakan formulasi pakan ikan perlu mempertimbangkan nilai gizi bahan yang akan digunakan.

Secara umum pelaksanaan pelatihan dapat berjalan dengan baik dan khalayak sasaran menjadi lebih inovatif serta mandiri dalam penyediaan pakan ikan. Dampak positif yang timbul paska pelatihan adalah berkurangnya biaya pembelian pakan dan mampu meningkatkan keindahan serta kebersihan lingkungan.

\section{Kesimpulan}

Anggota kelompok pembudidaya ikan RT 01/RW03 dan RT 02/RW06 Desa Karangnangka Kabupaten Banyumas telah mengalami peningkatan pengetahuan dan 
Wibowo, D.N., Bhagawati, D., Widyastuti, A., Kolya, E., Kusbiyanto, Indarmawan, Rukayah, S. Peningkatan...

keterampilan dalam membuat pakan ikan yang disuplementasi dengan tepung limbah sayuran dan bahan lokal lainnya. Selain itu, pelet yang dibuat mampu mendukung kelangsungan hidup dan pertumbuhan benih ikan nila, yang didederkan dalam kolam terpal.

\section{Ucapan Terima Kasih}

Penulis menyampaikan terima kasih kepada LPPM Unsoed yang telah memfasilitasi kegiatan alih teknologi ini melalui hibah kompetitif pengabdian kepada masyarakat yang didanai dari dana BLU Universitas Soedirman.

\section{Referensi}

Afandi, A. (2020). Participatory Action Research (PAR) Metodologi Alternatif Riset dan Pengabdian Kepada Masyarakat Transformatif. In Workshop Pengabdian Berbasis Riset di LP2M UIN Maulana Malik Ibrahim Malang.

Ali, F. (2015). Modul Pelatihan Membuat Pakan Ikan dan Udang. LIPI Press. Jakarta

Badan Litbang Pertanian. (2013). Pemanfaatan Limbah Pasar Sebagai Pakan Ruminansia Sapi dan Kambing Di DKI Jakarta. Agroinovasi. Edisi 4 - 10 September 2013 No.3522 Tahun XLIV. https://www.litbang.pertanian.go.id/download/227/file/PEMANFAATAN-LIMBAH-PASARS.pdf.

Badan Standarisasi Nasional.(2006). SNI 01-7242-2006. Pakan Buatan Untuk Ikan Nila (Oreochromis spp) Pada Budidaya Intensif.

Badan Standarisasi Nasional. (2009). SNI 7550:2009 tentang Produksi ikan nila (Oreochromis niloticus Bleeker) Kelas Pembesaran di Kolam Air Tenang

Bhagawati, D., Rukayah, S., Nuryanto, A., \& Sukirno, S. (2019). Penguatan Usaha Budidaya Ikan dengan Produksi Pakan Buatan Secara Mandiri. Dinamika Journal: Pengabdian Masyarakat, 1(4),1-11. http://dx.doi.org/10.20884/1.dj.2019.1.4.911

Insan, M., Priyambodo, B., \& Muliasari, H. (2020). Pelatihan pembuatan pakan gel berbasis bahan lokal sebagai pakan alternatif budidaya lobster di Pulau Lombok. Transformasi: Jurnal Pengabdian Masyarakat, 16(1), 1-11. https://doi.org/10.20414/transformasi.v16i1.2106

Masyamsir. (2001).Membuat Pakan Ikan Buatan. Departemen Pendidikan Nasional. Jakarta.

Millamena, O. M., Coloso, R. M., Pascual, F. P. (2002). Nutrition in Tropical Aquaculture: essentials of fish nutrition, feeds, and feeding of tropical aquatic species. Aquaculture Department, Southeast Asian Fisheries Development Center.

Rusmana, D., Abun \& D. Saefulhadjar. (2007). Pengaruh Pengolahan Limbah Sayuran secara Mekanis terhadap Kecernaan dan Efisiensi Penggunaan Protein pada Ayam Kampung Super. Lembaga Penelitian Universitas Padjajaran, Bandung.

Saade, E. \& Aslamyah, S. (2009). Uji fisik dan kimiawi pakan buatan untuk udang windu Penaeus monodon fab. yang menggunakan berbagai jenis rumput laut sebagai bahan perekat. Torani. Jurnal IImu Kelautan dan Perikanan. 19(2), 107-115

Suyanto, R. 2005. Nila. Penebar Swadaya. Jakarta.

Tiani, T., \& Narayana, Y. (2018). Teknik Pemeliharaan Larva Ikan Nila Genetically Male Tilapia GMT (Oreocremis niloticus) Di Balai Besar Pengembangan Budidaya Air Tawar (BBPBAT) Sukabumi, Jawa Barat. In Prosiding Seminar Nasional Sinergitas Multidisiplin Ilmu Pengetahuan dan Teknologi (Vol. 1, pp. 144-150).

Widyastuti, E., D.N. Wibowo \& Carmudi. (2014). Konservasi Sumberdaya Hayati di Waduk Penjalin dengan Budidaya Ikan Nila Menggunakan Pakan Fermentasi dan Suplementasi Daun Caisim serta Probiotik. Laporan.Fakultas Biologi Unsoed, Purwokerto.

Yulianto, T. (2018). Uji stabilitas, daya apung dan warna serta aroma pada pelet yang berbeda. Dinamika Maritim, 6(2), 5-8. 